\title{
ALTERNATIVE COMPOSITIONS OF ORIENTED STRAND BOARDS (OSB) MADE WITH COMMERCIAL WOODS PRODUCED IN BRAZIL
}

\author{
Lina Bufalino ${ }^{l, \AA}$, Andrea Aparecida Ribeiro Corrêa ${ }^{2}$, Vânia Aparecida de Sá̉, \\ Lourival Marin Mendes ${ }^{4}$, Natália Amarante Almeida ${ }^{5}$, Vinnicius Dordenoni Pizzol ${ }^{6}$
}

\begin{abstract}
This work aimed to investigate the feasibility of using and mixing Toona ciliata, Eucalyptus grandis/ urophylla and Pinus oocarpa woods in OSB production. Three one-species and four mixed-species combinations were compared. Layer structure varied by positioning different wood species in the surface and core of the panels. Phenol-formaldehyde (PF) adhesive was applied at $9 \%$ for all OSB panels. Three-layer mats with mass proportion of $25 / 50 / 25 \%$ for surface/core/surface were produced. Pressing time was 8 min, under a $4 \mathrm{MPa}$ pressure and temperature of $180^{\circ} \mathrm{C}$. Physical and mechanical properties were evaluated and compared to EN (300) commercialization standard. Most OSB panels did not fully attain such requirements. OSB panels made with Eucalyptus grandis/urophylla and Pinus oocarpa woods have potential to be commercialized as $O S B / 1$ and $O S B / 2$ types, respectively. Among panels made with $T$. ciliata wood, those produced with this species in the surface and Eucalyptus grandis/urophylla wood in the core met the requirements established for OSB/1 commercialization. Eucalyptus wood has great potential to substitute Pinus wood in OSB production. The utilization of $T$. ciliata wood for OSB production decreased mechanical performance, but remarkably enhanced water resistance properties.
\end{abstract}

Keywords: Compression ratio, Eucalyptus grandis $x$ urophylla, hardwoods, mechanical properties, physical properties, Pinus oocarpa, Toona ciliata.

\section{INTRODUCTION}

Oriented strand board (OSB) was introduced into the construction market in the early 1980s. The OSB industry posted rapid growth and is now well established across North America and Europe (Barbuta et al. 2011). Along with Medium Density Fiberboard (MDF), OSB is slowly replacing the use of sawn wood for furniture and moulding in developed countries. In South America, Chile and Brazil are the main producers, where OSB is currently replacing more expensive plywood (EFORWOOD 2013, Okino et al. 2004). The use of small-diameter, low quality logs as raw material for OSB production is the main advantage of this woodbased product (Barbuta et al. 2011). In Brazil, the OSB industrial plant is located at Ponta Grossa in Paraná state (south region) with a capacity of $350000 \mathrm{~m}^{3} \mathrm{year}^{-1}$. Main applications in Brazil include I-beams, wood frame and steel frame systems, coatings, roofs and walls.

Silvicultural activity in Brazil is mainly focused on Eucalyptus and Pinus species because they have relatively fast growing rates and are low-cost raw materials for the wood industries, in comparison to commercial tropical woods (Pincelli et al. 2012). OSB national production is exclusively represented by Pinus species. A drawback to this current scenario is the decreasing production of softwoods in Brazil that may hinder particleboard production. From 2010 to 2011 Eucalyptus planted area increased 2,5\% from 2010

\footnotetext{
'PhD. candidate in Wood Science and Technology, Department of Forest Science, Federal University of Lavras. Lavras, Brazil P.0. Box 3037, 37200-000, Lavras/MG, Brazil ${ }^{2} \mathrm{PhD}$. candidate in Wood Science and Technology, Department of Forest Science, Federal University of Lavras. Lavras, Brazil P.0. Box 3037, 37200-000, Lavras/MG, Brazil ${ }^{3} \mathrm{PhD}$. candidate in Wood Science and Technology, Department of Forest Science, Federal University of Lavras. Lavras, Brazil P.O. Box 3037, 37200-000, Lavras/MG, Brazil. ${ }^{4}$ Associate professor II, Department of Forest Science, Federal University of Lavras. Lavras, Brazil P.O. Box 3037, 37200-000, Lavras/MG, Brazil.

${ }^{5}$ Master in Wood Science and Technology, Department of Forest Science, Federal University of Lavras. Lavras, Brazil P.O. Box 3037, 37200-000, Lavras/MG, Brazil ${ }^{6}$ Master in Wood Science and Technology, Department of Forest Science, Federal University of Lavras. Lavras, Brazil P.O. Box 3037, 37200-000, Lavras/MG, Brazil Received: 10.02.2013 Accepted: 27.03. 2014 Corresponding author: linabufalino@yahoo.com.br
} 
to 2011, while Pinus planted area decreased 6,5\%. Even in Paraná state, which is the main producer, Pinus planted area reduction was remarkable (ABRAF 2012). This new context of planted forest strongly suggests the need for wood diversification as raw materials for OSB production.

Highly-prized hardwoods, which have formerly been resourced from native forests, are now being cultivated in plantations. Australian red cedar (Toona ciliata M. Roem var. australis), which belongs to the valuable Meliacea family has stood out as a planted forestry species in tropical and subtropical American countries (Dordel et al. 2010). T. ciliata extends naturally from eastern Pakistan and India through Southeast Asia and Southern China and through Hainan Island to the Philippines and Eastern Australia (Heirinch and Banks 2006). This natural habitat has been widely destroyed due to exploitation. Damage by the Hypsipyla robusta shoot borer is the main factor hindering the regeneration of $T$. ciliata. However, this plague does not naturally occur in America (Bygrave and Bygrave 2005, Cunningham et al. 2005). In Brazil this species found favorable environmental conditions in Southeast and South Bahia regions. Its expected national productivity is from 250 to $300 \mathrm{~m}^{3} \mathrm{ha}^{-1}$ for 20-year-old plantations (CIflorestas 2013).

Previous works have shown the potential of T. ciliata wood for the production of a wide range of woodbased products, among which high quality-saw wood (Silva et al. 2010), conventional particleboards (Bufalino et al. 2012a), plywood (Albino et al. 2011) and cement-wood boards (Sá et al. 2012, Sá et al. 2010). Until the present, there are no works in the literature that applied T. ciliata wood in OSB production. T. ciliata from the Meliaceae family produces high value wood, but its primary processing will result in waste generation. In addition, thinning is necessary to grow high-diameter trees for sawing. Wood wastes such as slabs and thinning sub-products could be used for the production of several types of boards as an interesting alternative to assure a more sustainable use of biomass. This work aimed to investigate the feasibility of using and mixing T. ciliata, Eucalyptus hybrid and Pinus oocarpa woods in OSB production.

\section{MATERIALS AND METHODS}

\section{Materials}

Raw materials used to manufacture OSB in this study were: (1) 18-year-old Pinus oocarpa wood obtained from an experimental plantation located at Lavras, Minas Gerais, Brazil; (2) 7-year-old Eucalyptus grandis/ urophylla hybrid clone wood, obtained from the Companhia Mineira de Metais located at Vazantes, Minas Gerais, Brazil, and (3) residual slabs from the primary processing of 18-year-old Toona ciliata var. australis obtained from a commercial plantation located at Marechal Floriano, Espírito Santo, Brazil. Commercial phenol-formaldehyde $(P F)$ adhesive with solid content of $46,8 \%$ was used. The wood species were characterized by basic density, determined according to the NBR 11942 (ABNT 2003) and chemical analyses. Total extractives and lignin contents were determined in accordance with M3/69 (ABTCP 1974a) and M70/71 (ABTCP 1974b) standards respectively, using three replicates.

\section{OSB Manufacture and Evaluation}

The slabs from T. ciliata and E. grandis/urophylla and $P$. oocarpa lumbers were transformed into $20 \mathrm{~cm} \mathrm{x}$ $9 \mathrm{~cm} \times 2,5 \mathrm{~cm}$ pieces which were reduced to strand particles with target dimensions of $9 \mathrm{~cm} \times 2,5 \mathrm{~cm} \times 0,7 \mathrm{~mm}$ in a laboratory slicer. Previous laboratory studies showed that OSB made with T. ciliata blow during pressing (Bufalino et al. 2012b). This result was mainly attributed to high content of volatile extractives. Therefore, previously to board making, T. ciliata wood strands were immersed in water for $24 \mathrm{~h}$ at a ratio of $5 \mathrm{~kg}$ of wood particles to 10001 of water, at room temperature. The particles were subsequently dried and screened in order to eliminate fines and wood dust. The final moisture content of the strands ranged from $1,5 \%$ to $3 \%$. 
The blending of the strands with adhesive and wax was performed using a laboratory drum blender. $P F$ adhesive was applied at $9 \%$ for all OSB panels, both in the surface layers and the core layer. The adhesive loading used in this study is above the usually used in the literature and in the OSB industry because T. ciliata has a remarkably low basic density, hence a high superficial area to be covered by the adhesive and glued. Previous laboratory studies showed that lower adhesive levels did not allow board consolidation. Strand orientation was achieved by dropping the strands through a mesh with adjustable parallel plates. Three-layer mats were formed in such a way as to ensure that the surface layers were perpendicular to the core layer. The mass proportion was $25 / 50 / 25 \%$ for surface/core/surface of the boards.

A manual press machine was used to perform a pre-pressing procedure until $2000 \mathrm{~kg}$. The mats were then put in a hydraulic press and the boards were pressed using a press time of $8 \mathrm{~min}$, under a 4 MPa pressure and a temperature of $180{ }^{\circ} \mathrm{C}$. Target apparent density of $650 \mathrm{kgm}^{-3}$ and board dimension of 48,5 $\mathrm{cm} \mathrm{x} \mathrm{48,5}$ $\mathrm{cm}$ x 1,5 cm were held constant. Three OSB panels of each combination depicted in Table 1 were produced.

Table 1. Wood composition of the OSB panels.

\begin{tabular}{cccc}
\hline Symbol & Surface & Core & Surface \\
\hline T-OSB & T. ciliata & T. ciliata & T. ciliata \\
P-OSB & P. oocarpa & P. oocarpa & P. oocarpa \\
E-OSB & E. grandis/urophylla & E. grandis/urophylla & E. grandis/urophylla \\
PTP-OSB & P. oocarpa & T. ciliata & P. oocarpa \\
ETE-OSB & E. grandis/urophylla & T. ciliata & E. grandis/urophylla \\
TPT-OSB & T. ciliata & P. oocarpa & T. ciliata \\
TET-OSB & T. ciliata & E. grandis $/$ urophylla & T. ciliata \\
\hline
\end{tabular}

The samples were stabilized in a conditioning room $\left(20 \pm 1{ }^{\circ} \mathrm{C}\right.$ and $\left.65 \pm 3 \% \mathrm{RH}\right)$. The following physical and mechanical properties were evaluated: water absorption after immersion for $2 \mathrm{~h}(W A 2 h)$ and $24 \mathrm{~h}(W A 24 h)$; thickness swelling after immersion for $2 \mathrm{~h}$ (TS2h) and $24 \mathrm{~h}$ (TS24h); measured apparent density; modulus of elasticity (MOE) and modulus of rupture (MOR) in static bending; and internal bond (IB). Compression ratio $(C R)$ was calculated by dividing the average measured apparent density of the panels by the respective wood basic density. For panels made from two wood species ( $50 \%$ each), an arithmetic average of their basic densities was considered. Static bending test was performed in specimens with particles in the parallel $(/ /)$ and perpendicular $\left({ }^{\perp}\right)$ directions in relation to their surface layer. For mechanical tests, a universal testing machine (EMIC DL-30000) was used. Physical properties and internal bond were determined in accordance with ASTM D 1037-100 (ASTM 2006) standard procedures. Static bending test was carried out following DIN 52362 (DIN 1982) standard recommendations. Figure 1 depicts specimen distribution and number obtained in the OSB panels. 


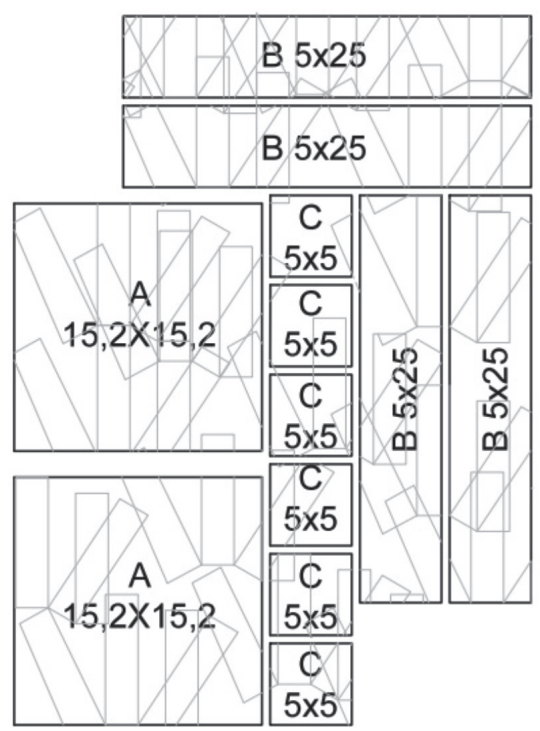

Figure 1. a) Measured apparent density, water absorption 2h (WA2h), water absorption 24h (WA24h), thickness swelling $2 \mathrm{~h}$ (TS2h) and thickness swelling 24h (TS24h); b) Static bending; c) Internal bond (IB).

Data was statistically analyzed by means of average and standard deviation. The boards were evaluated according to EN 300 (2003) standard, which classifies OSB types as follows: 1) OSB/1 - General purpose boards and boards for interior fitments (including furniture) for use in dry conditions; 2) $O S B / 2$ - Load-bearing boards for use in dry conditions; 3 ) $O S B / 3$ - Load bearing boards for use in humid conditions; 4) $O S B / 4$ Heavy duty load-bearing boards for use in humid conditions.

\section{RESULTS AND DISCUSSION}

\section{Wood species and OSB basic characterization}

The characterization of the wood species investigated is depicted in Table 2. T. ciliata and P. oocarpa woods have similar basic density, while E. grandis/urophylla wood has higher basic density. Wood basic density is the most important property to be considered in OSB production; it should range from 300 to 500 $\mathrm{kgm}^{-}{ }^{3}$ in order to result in panels with a high $C R$, which is the ratio given by the mean apparent board density divided by the mean wood basic density (Maloney 1993).

Regarding chemical composition, high extractive content found for T. ciliata may result in gluing and pressing problems during board production. During a previous laboratory study OSB produced with $T$. ciliata blew during pressing process due to evaporation of volatile extractives. A previous study with the same T. ciliata wood material used in this work showed that water immersion treatment decreased extractive content from 12,93 to 9,56\% and allowed board production (Bufalino et al. 2012b). On the other hand, high contents of extractive in this species results in high natural resistance to termites and fungi (Ribeiro 2011, Almeida 2012).

Higher lignin content accounts as an advantage for board production because this chemical component imparts hydrophobicity to wood cells (Joseleau 2004). In addition, lignin is natural binder that may contribute to bond enhancement of the board strength (Khedari et al. 2004). 
Table 2. Physical and chemical characterization of the wood species.

\begin{tabular}{cccc}
\hline Wood & $\begin{array}{c}\text { Basic density } \\
\left(\mathrm{kgm}^{-3}\right)\end{array}$ & $\begin{array}{c}\text { Extractive content } \\
(\%)\end{array}$ & $\begin{array}{c}\text { Lignin content } \\
(\%)\end{array}$ \\
\hline T. ciliata & 320 & 12,9 & 24,4 \\
P. oocarpa & 360 & 6,3 & 26,7 \\
E. grandis/urophylla & 530 & 6,8 & 22,8 \\
\hline
\end{tabular}

Measured apparent density was close to the established value of $650 \mathrm{kgm}^{-3}$, while high variation was obtained for $C R$ of the OSB panels (Table 3).

Table 3. Measured apparent density and compression ratio values of the OSB panels.

\begin{tabular}{cccc}
\hline $\begin{array}{c}\text { OSB } \\
\text { specification }\end{array}$ & $\begin{array}{c}\text { Measured apparent } \\
\text { density of panels }\left(\mathrm{kgm}^{-3}\right)\end{array}$ & $\begin{array}{c}\text { Average wood basic } \\
\text { density }\left(\mathrm{kgm}^{-3}\right)\end{array}$ & $\begin{array}{c}\text { Compression } \\
\text { Ratio }\end{array}$ \\
\hline$T-O S B$ & $590(30 *)$ & 320 & 1,84 \\
$P-O S B$ & $680(62)$ & 360 & 1,89 \\
$E-O S B$ & $684(24)$ & 530 & 1,29 \\
$E T E-O S B$ & $647(19)$ & 420 & 1,54 \\
$T E T-O S B$ & $651(45)$ & 420 & 1,55 \\
$P T P-O S B$ & $655(18)$ & 340 & 1,93 \\
$T P T-O S B$ & $653(12)$ & 340 & 1,92 \\
\hline
\end{tabular}

* Standard deviation values

Compression ratio $(C R)$ is closely related to the physical and mechanical properties of all particleboards. Better mechanical performances of the boards are expected with higher $C R$, while effects for physical properties may vary (Bufalino et al. 2012a).

\section{Water resistance properties}

$W A$ values varied among different OSB wood composition and ranged from 32 to $66 \%$ for $W A 2 h$ and from 55 to $85 \%$ for $W A 24 h$ (Figure 2). Among panels produced with one species, T-OSB panels had remarkably low $W A$ values. Considering high $C R$ of such boards, this result could be mainly attributed to few voids in the mat microstructure. High densification works as a barrier to water entrance resulting in lower $W A$. On the other hand, $C R$ value of $P$-OSB panels was very similar to that found for T-OSB panels. Therefore, the higher resistance found for $T$-OSB panels may also be related to the presence of hydrophobic extractives in the wood surface. It should be noticed that by placing T. ciliata particles in the surface of TPT-OSB and TET$O S B$ panels, water resistance improved in comparison to $P-O S B$ and $E-O S B$ panels. 


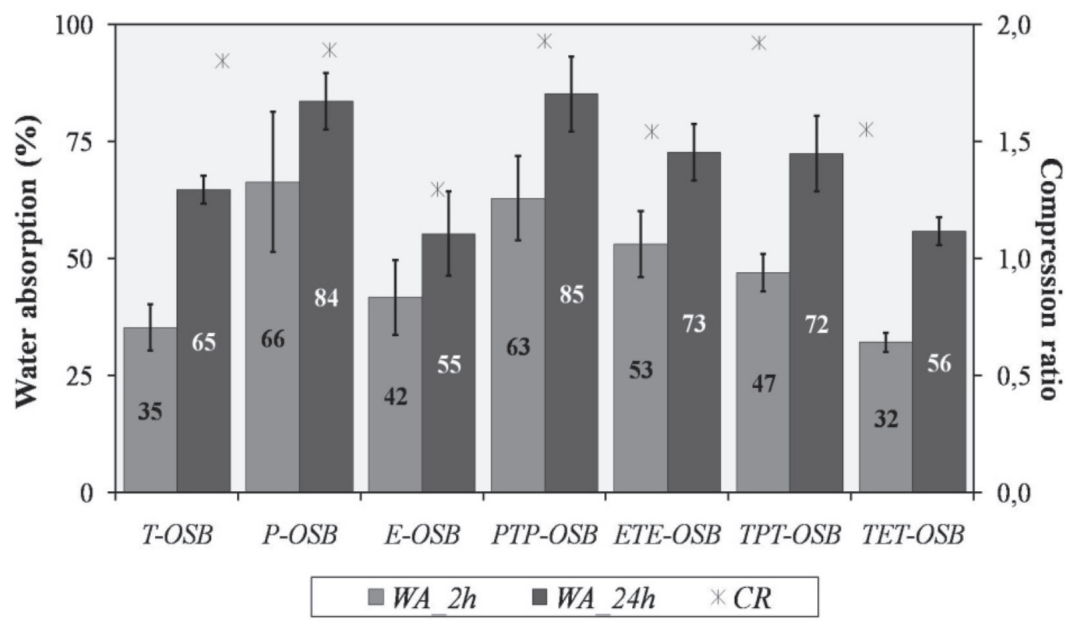

Figure 2. Average values and standard deviation of water absorption $2 \mathrm{~h}(W A 2 h)$ and water absorption $24 \mathrm{~h}$ (WA24h).

Although $E$-OSB panels had the lowest $C R$, WA values were lower than those found for $P$-OSB panels. Lower total superficial wood area available for water entrance certainly leaded to this result. The inclusion of $P$. oocarpa in the TPT-OSB and PTP-OSB panels increased water absorption in relation to TET-OSB and ETE-OSB panels, respectively.

EN (300) standard does not establish maximum values of $W A$. Comparisons to the literature show that $W A 24 h$ values obtained in this investigation were similar to those presented for OSB panels produced with $P F$ applied at $8 \%$ and Pinus taeda (Okino et al. 2004). For most OSB compositions $W A$ values were in accordance to those found for non-treated Picea abies wood particles and 5\% of PF (Papadoulos and Traboulay 2002). However, OSB panels comprised of T. ciliata showed lower values when compared to the same investigation. It is important to mention that higher adhesive content and lower board density were used in the present work.

$T S$ values of the OSB panels along with the maximum value of TS24h required by EN 300 (EN 2003) standard for board commercialization are depicted in Figure 3. TS2 $h$ varied from 10 to 26\%, while for TS24h the values ranged from 14 to $30 \%$.

The dimensional changes in OSB panels during water soaking result mainly from the swelling of the fiber cell walls due to water absorption that resides in the inter-strand voids, disintegration of particles due to bonding strength reduction, and spring-back of the compression set imposed during the hot pressing operation (van Houts et al. 2004, Zhang et al. 1998).

High $T S$ values found for boards produced with $P$. oocarpa may be related to high $C R$. Although increases in $C R$ are usually desirable due to mechanical strength improvement, higher dimensional instability can be a negative effect. When OSB panels are submitted to water submersion, internal forces are released and result in panel swelling. This phenomenon is called spring back and it is stronger when highly densification occurs during pressing process, which in turn, is related to low basic density-woods or higher board density (Hiziroglu 2009, Zhang et al. 1998). On the other hand, T-OSB panels had high CR, but high swelling was not observed which corroborates with $W A$ results and possible wood extractive effect. The inclusion of $T$. ciliata wood enhanced dimensional stability of the boards made from this species mixed with $P$. oocarpa and $E$. urophylla/grandis, especially when positioned in the surface. A similar effect on TS24h was observed in the literature for conventional particleboards produced with the same species of this work (Bufalino et al. 2012a). 
Regarding TS for board commercialization, $P O-O S B, P T P-O S B$ and ETE-OSB panels are not feasible. The same may be considered for TPT-OSB panels, if standard deviation is considered. TET-OSB and E-OSB panels have potential to be commercialized as $O S B / 1$, but not as $O S B / 2$. Only $T-O S B$ have potential to be commercialized as $O S B / 2$, when $T S 24 h$ is considered.

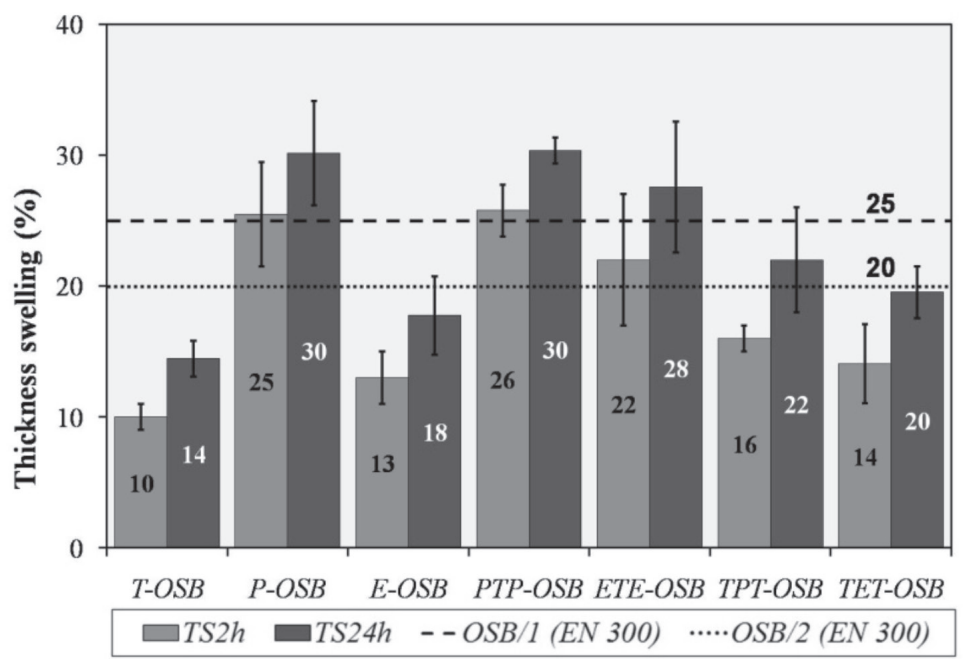

Figure 3. Average values and standard deviation of thickness swelling $2 \mathrm{~h}$ (TS2h) and thickness swelling 24h (TS24h).

\section{Mechanical properties of OSB panels}

Among one-species OSB panels, higher $I B$ was found for $E-O S B$ and $P$-OSB in comparison to T-OSB panels. Considering mixed panels, the highest bond strength was found for TET-OSB panels (Figure 4). The utilization of low-density species increases the number of strands used, resulting in a higher total wood surface area of the strands and a lower area covered by the adhesive (Barbuta et al. 2011). Such effect may have occurred in $T-O S B$ panels. On the other hand, $P-O S B$ panels had similar $C R$, and $I B$ was remarkably higher. Besides high $C R$, poor $I B$ strength found for $T-O S B$ panels may also be attributed to high extractive content in T. ciliata wood species.

Extractives on wood contribute to surface inactivation through both physical and mechanical means. Most wood adhesives are water-based and hence do not properly wet and penetrate extractive-covered surfaces. Physical blocking occurs when the wood is submitted to high temperatures causing extractive migration to the surface where they concentrate and physically block contact with wood (Frihart and Hunt 2010). Although water pre-treatment was performed in T. ciliata wood, stronger chemical extractive removal should be considered in further studies in order to improve bond strength. By comparing TET-OSB with ETE-OSB panels, it can be noticed that by placing $T$. ciliata in the core, $I B$ strength decreases. Combination between P. oocarpa and T. ciliata resulted in poor $I B$ strength. 


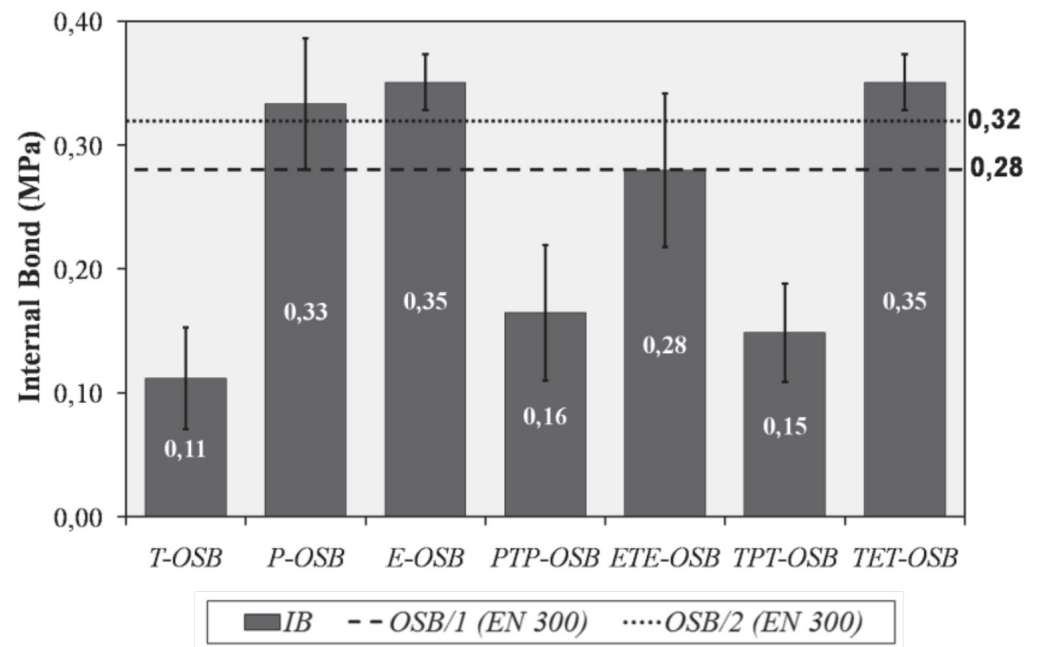

Figure 4. Average values and standard deviation of internal bond (IB).

According to the requirements established by EN (300) standard for $I B$ strenght, $P$-OSB, E-OSB and TET panels have potential to be commercialized as both $O S B / 1$ and $O S B / 2$ board types. Most $I B$ strengh values were poor and did not met the standard requirements.

The results from static bending test are depicted in Figures 5-8. Regarding one-species OSB, overall static bending results place $P-O S B$ as most resistant. This result may be partially ascribed to higher $I B$ and $C R$ found for such boards. A greater volume of wood particles compacted during pressing process increases inter-particle contact. Along with adequate bonding quality, panels will have higher strength to external forces. Although $T-O S B$ panels had high $C R$, bonding strength was poor and certainly influenced static bending properties. Considering standard deviation, OSB composed by two species had similar static bending strength.

Higher mean values obtained in tests performed in specimens with parallel alignment of particles in the core $(/ /)$ compared to those obtained in perpendicular alignment $(\perp)$ suggests that face/core/face ratio $(\%$ mass $)$ used is not adequate in terms of balanced composition (Mendes et al. 2009). Among compositions studied, most similar results between test directions were found for $P$-OSB, while results for TET-OSB suggest that another surface/core/surface ratio should be used.

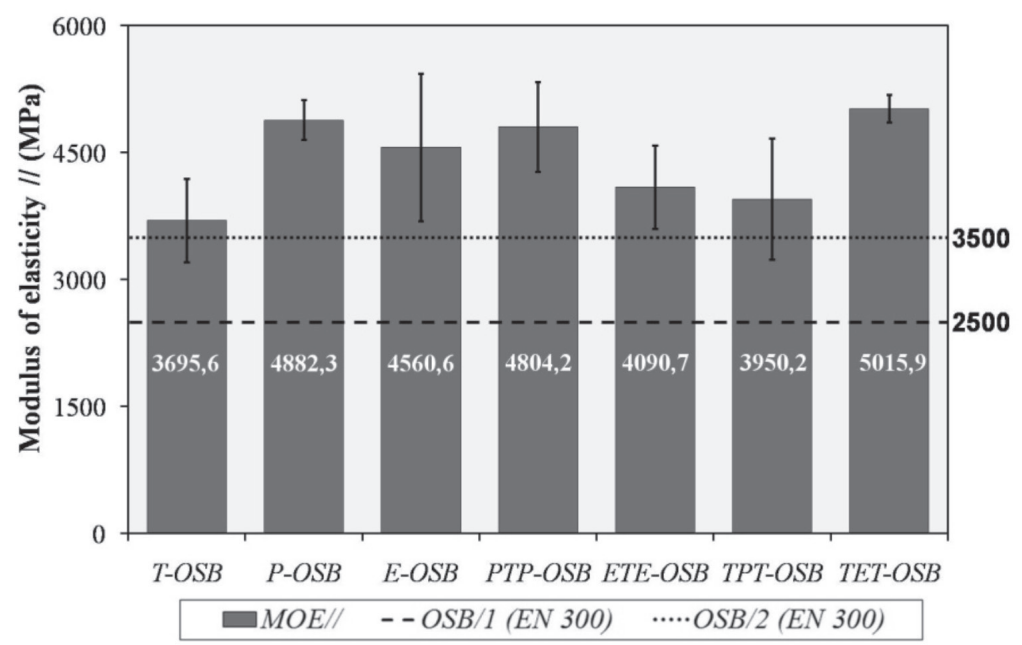

Figure 5. Average values and standard deviation of modulus of elasticity $(M O E / /)$. 


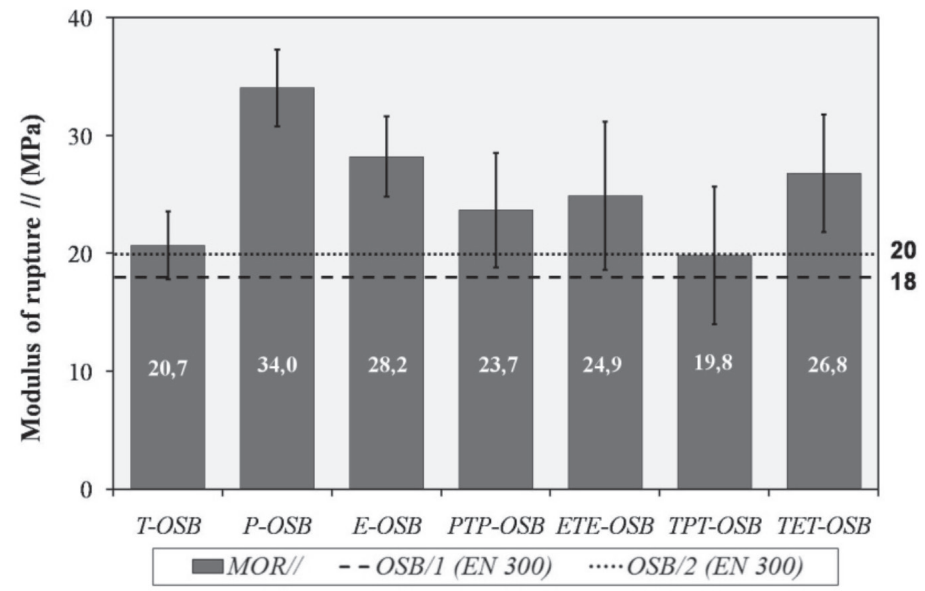

Figure 6. Average values and standard deviation of modulus of rupture (MOR//).

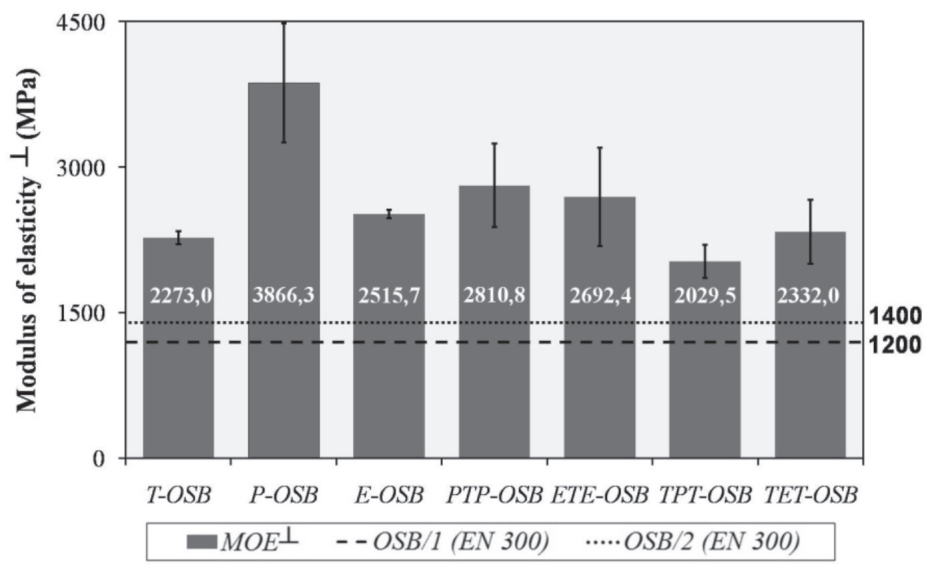

Figure 7. Average values and standard deviation of modulus of elasticity $\left(M O E^{\perp}\right)$.

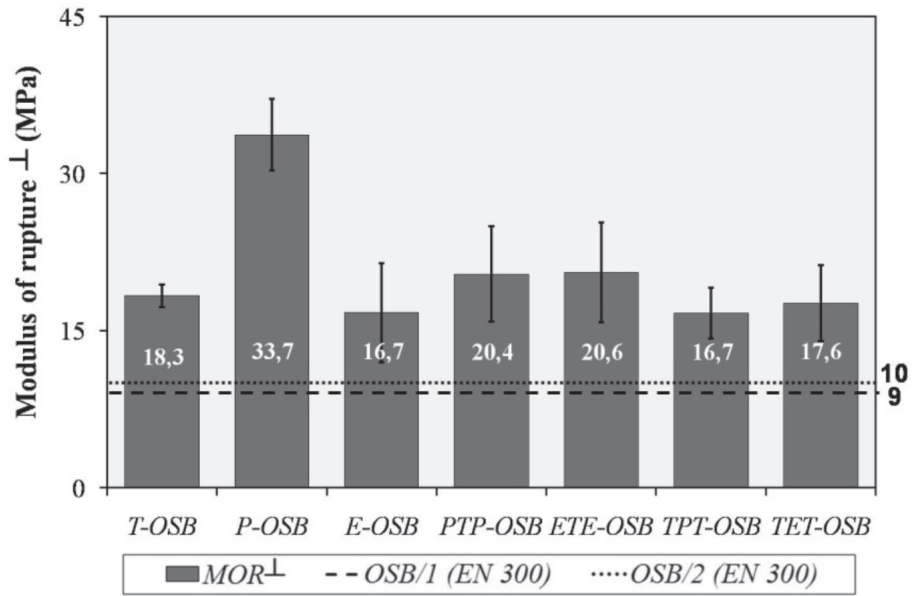

Figure 8. Average values and standard deviation of modulus of rupture $\left(M O R^{\perp}\right)$. 
Most board compositions showed bending strength values in both directions of strands alignment (// and $\perp$ ) superior to those required by EN (300) standard, for boards classified as $O S B / 1$ and $O S B / 2$. T-OSB have potential to be commercialized only as $O S B / 1$, while TPT-OSB did not met the requirement for $M O R / /$.

\section{CONCLUSIONS}

Considering all mechanical and physical properties evaluated in the present work, $P$-OSB type has potential to be commercialized as $O S B / 1$ type, while $E-O S B$ and TET-OSB met all the requirements for $O S B / 2$ type. The others OSB compositions did not fully attend the requirements for commercialization.

In general, bonding performance is the main drawback in the use of T. ciliata for OSB production; hence an improvement has to be attained in order to reach standard requirements. In general, static bending strength was lower when this species was included in panel composition. However, all panel compositions proposed met the European standard requirements for $M O R^{\perp}$ and $M O E^{\perp}$ properties, while most compositions attended the requirements for $M O E / /$ and $M O R / /$.

Low basic density of $T$. ciliata requires the use of high adhesive level, which increases the production cost of the boards. In order to assure commercial feasibility of the compositions proposed in this work, further studies are needed to provide strong bond quality with lower adhesive contents. On the other hand, remarkable improvement of water uptake resistance and dimensional stability was observed with this species utilization. High extractive content found in this species may represent a negative effect on mechanical resistance, but a positive effect on water resistance properties. Since high TS is one of the main issues in OSB applications, $T$. ciliata wood species has great potential for the production of these wood-based products.

\section{ACKNOWLEDGMENT}

The authors are grateful for the support of the Coordination for the Improvement of Higher Level Personnel (CAPES), the Minas Gerais State Research Foundation (Fapemig), the National Council for Scientific and Technological Development (CNPq), and the Brazilian Research Network in Lignocellulosic Composites and Nanocomposites (RELIGAR).

\section{REFERENCES}

Associação Brasileira de Normas Técnicas. ABNT. 2003. NBR 11942. "Madeira—determinação da densidade básica", Rio de Janeiro. Brazil.

Associação Brasileira de Florestas Plantadas. ABRAF . 2012. Anuário Estatístico da ABRAF. [on line] $<$ http://www.bibliotecaflorestal.ufv.br/handle/123456789/3909>. [Consulta: Enero 2013].

Associação Brasileira Técnica de Celulose e Papel. ABTCP. 1974a. ABTCP-M3/69. Métodos de ensaio. "Associação Brasileira Técnica de Celulose e Papel”, São Paulo. Brazil.

Associação Brasileira Técnica de Celulose e Papel. ABTCP. 1974b. Métodos de ensaio. ABTCPM70/71. São Paulo. Brazil.

Albino, V.C.S.; Sá, V.A.; Bufalino, L.; Mendes, L.M.; Almeida, N.A. 2011. Avaliação das propriedades físico-mecânicas de painéis compensados de Toona ciliata M. Roem. var. australis. Cerne 17(1):103-108. 
Almeida, N.A.; Mendes, L.M.; Okino, E.Y.A.; Garlet, A.; Mori, F.A.; Mendes, R.F. 2012. Biodeterioração de produtos a base de madeira de cedro australiano (Toona ciliata M. Roem. var. australis) Cerne 18(1): 17-26.

American Society for testing and materials. ASTM. 2006. ASTM-1037. Standard methods of evaluating properties of wood-base fiber and particle materials. Philadelphia. United States of America.

Barbuta, C.; Cloutier, A.; Blanchet, P., Yadama, V.; Lowell, E. 2011. Tailor made OSB for special application. European Journal of Wood Products 69(4):511-519.

Bufalino, L.; Albino, V.C.S.; Sá, V.A.; Correa, A.R.R.; Mendes, L.M.; Almeida, N.A. 2012a. Particleboards made from Australian red cedar: processing variables and evaluation of mixed species. Journal of Tropical Forest Science 24(2): 162-172.

Bufalino, L.; Protásio, T.P.P.; Couto, A.M.; Nassur, O.A.C.; Sá, V.A.; Trugilho, P.F.; Mendes, L.M. 2012b. Caracterização química e energética para aproveitamento da madeira de costaneira e desbaste de cedro australiano. Pesquisa Florestal Brasileira 32(70): 129-137.

Bygrave, F.L.; Bygrave, P.L. 2005. Growing Australian Red Cedar. Sidney, RIRDC/Land \& Water Australian/FWPRDE/MDBC, 76 p. [on line] <file:///C:/Users/Lina/Downloads/04-135.pdf> [Consulta: Julio 2014].

CIFlorestas - Centro de Inteligência em Florestas. 2013. [on line] $<$ http://www.ciflorestas.com.br/ texto.php?p=cedro_australiano>. [Consulta: Febrero 2013].

Cunningham, S.A.; Floyd, R.B.; Griffiths, M.W.; Wylie, F.R. 2005. Patterns of host use by the shootborer Hypsipyla robusta (Pyralidae: Lepidoptera) comparing five Meliaceae tree species in Asia and Australia. Forest Ecology and Management 205(1-3): 351-357.

Deutsches Institut für Normung. DIN. 1982. Testing of wood chipboards; bending test, determination of bending strength. DIN 52362. Berlin. Germany.

Dordel, J.; Simard, S.W.; Bauhaus, J.; Seely, B.; Pozas, L.J.; Prescott, C.; Hampel, H. 2010. Tradeoffs among establishment success, stem morphology and productivity of underplanted Toona ciliata. Forest Ecology and Management 259(9):1846-1855.

EFORWOOD. Sustainable Impact Assessment of the Forestry Wood Chain. 2008. Project ID: 518128 Thematic Priority: Global Change and Ecosystems Duration. [on line]<http://www.innovawood.com/ eforwood/LinkClick.aspx?fileticket=H6rOD\%2FJ730Y\%3D\&tabid=36\&mid=947> [Consulta: Enero 2013].

European Committee for Standardization. 2003. Particleboards-Specifications. EN 312-3: Particleboards-Specifications. Brussels.

Frihart, C.R.; Hunt, C.G. 2010. Adhesives with wood materials: bond formation and performance. Forest Products Laboratory, Madison.

Heinrich, I.; Banks, J.C.G. 2006. Variation in phenology, growth, and wood anatomy of Toona sinensis and Toona ciliata in relation to different environmental conditions. International Journal of Plant Sciences 167(4):831-841.

Hiziroglu, S. 2009. Properties of strandboard panels manufactured from Eastern Redcedar. Materials 2(3): 926-933. 
Joseleau, J.P.; Imai, T.; Kuroda, K.; Ruel, K. 2004. Detection in situ and characterization of lignin in the G layer of tension wood fibres of Populus deltoids. Planta 219(2): 338-345.

Khedari, J; Nankongnab, N; Hirunlabh, J; Teekasap, S. 2004. New low-cost insulation particleboards from mixture of durian peel and coconut coir. Building and Environment 39(1): 59-65.

Maloney, T.M. Modern particleboard and dry process fiberboard manufacturing. San Francisco, M. Freeman, 1993, 2 ed. M. Freeman. 681 p.

Mendes, L.M.; Iwakiri, S.; Mori, F.A.; Guimarães Júnior, J.B.; Mendes, R.F. 2009. Eucalyptus urophylla stands wood utilization at two different ages for production of particleboard panels. Cerne 15(3):288-294.

Okino, E.Y.A.; Teixeira, D.E.; Souza, M.R. de; Santana, M.A. E.; Sousa, M.E. de. 2004. Properties of oriented strandboard made of wood species from Brazilian planted forests: Part 1: $80 \mathrm{~mm}$-long strands of Pinus taeda L. Holz als Roh- und Werkstoff 62(3): 221-224.

Papadoulos, A.N.; Traboulay, E. 2002. Dimensional stability of OSB made from acetylated Fir strands. Holz als Roh- und Werkstoff 60(2): 84-87.

Pincelli, A.L.P.S.M.; Moura, L.F.; Brito, J.O. 2012. Effect of thermal rectification on colors of Eucalyptus saligna and Pinus caribaea woods. Maderas. Ciencia y tecnología 14(2):239-248.

Ribeiro, M.X. 2011. Resistência de painéis aglomerados a cupins de madeira seca. Master. Dissertation, Federal University of Lavras, Lavras, Brazil.

Sá, de V.A.; Bufalino, L.; Albino, V.C.S.; Côrrea, A.A.; Mendes, L.M.; Almeida, N.A. 2012. Mistura de três espécies de reflorestamento na produção de painéis cimento-madeira. Revista Árvore 36(3):549-557.

Sá, de V.A.; Mendes, L.M.; Couto, A.M.; Lima, N.N. 2010. Manufatura de painéis cimento-madeira de cedro australiano (Toona ciliata M. Roem var. australis). Scientia Forestalis 38(88):559-566.

Silva, J.R.M.; Alves, J.A.; Nogueira, M.O.G.; Braga, P.P.C. 2010. Qualificação da superfície acaba em madeiras de Eucalyptus grandis W. Hill ex Maiden, Toona ciliata M. Roemer e Coffea arabica L. Cerne $16: 15-22$.

Van Houts, J.H.; Wang, S.; Shi, H.; Pan, H.; Kabalka, G.W. 2004. Moisture movement and thickness swelling in oriented strandboard, part 1. Analysis using nuclear resonance microimaging. Wood Science Technology 38(8): 617-628.

Zhang, M.; Wong, E.; Kawai, S.; Kwon, J. 1998. Manufacture and properties of high-performance oriented strand board composite using thin strands. Journal of Wood Science 44(3): 191-197. 